\title{
Competitiveness and economic profit analysis of Kazakhstan's poultry companies
}

\author{
Petr Hájek \\ Unicorn College, \\ Crech Republic \\ bajekp@gmail.com
}

\section{Gulnar Zhunissova}

Al-Farabi Kazakh National University,

Kazakhstan

nietbaeva_gulnar@mail.ru

Zhanar Oralbaeva

Al-Farabi Kazakh National University,

Kazakbstan

oralbaeva_zhanar@mail.ru

\author{
Aknur Zhidebekkyzy \\ Al-Farabi Kazakh National University, \\ Kazakhstan \\ aknur.zh@gmail.com
}

\section{Adilya Baidildina}

Abai Kazakh National Pedagogical University,

Kazakhstan

adilya_11@mail.ru

Abstract. Measuring competitiveness in Central Asian post-socialist countries is problematic as many well-known metrics systems fail to warn about bankruptcy risks sufficiently early or at all. With 2013-2017 data, we have compared data on the selected poultry sector companies operating in Kazakhstan to analyze their competitiveness, while financial analysis metrics provided us with the financial performance data. In particular, we have analyzed two publicly traded companies - Alatau-Kus JSC and Ust-Kamenogorskaya pticefabrika JSC, and two non-publicly traded companies - Alel-Agro JSC, and Sever Ptica JSC. These are compared with the largest Czech poultry meat producer Vodnanska drubez, JSC. Firstly, we measured competitiveness through bankruptcy and creditworthiness models and compared competitiveness as compared to financial situation of the main competitors at that market. To measure competitiveness, we used such indicators as IN99, IN01, IN05. We show the IN models can be beneficial in the case of the post-socialist countries. By using

Received: October, 2018 1st Revision: January, 2019

Accepted: April, 2019

DOI: $10.14254 / 2071$ $8330.2019 / 12-2 / 9$ 
INFA, we have aimed to confirm that only financially healthy companies, producing economic value added, can be competitive in the long run. For this analysis, we have additionally compared data with those of Czech food industry. We show that Czech INFA metrics system can serve as a very useful indicator for competitiveness analysis of Kazakhstan companies.

Keywords: EVA, INFA, bankruptcy models, performance evaluation, competitiveness, score models, poultry sector, Kazakhstan.

JEL Classification: G32, G33

\section{INTRODUCTION}

Kazakhstan is a large country where chicken meat is very popular, and its production has been increasing since 2010. There are plans to increase production even further so the market share of domestic producers will increase and import will fall in both areas of poultry business, production of poultry meat and eggs. Unfortunately, to our knowledge, no analyses exist on Kazakh companies operating in this sector.

We show IN bankruptcy in comparison to other indexes in the analyzed environment. We want to show that the IN models can be beneficial in the post-socialist countries and used at least next to famous Altman or Taffler z-score models because they reflect certain events or corporate situations in a much clearer way. Hence, we consider IN models to be appropriate for analyses of the companies operating in Kazakhstan. Secondly, we also calculate Economic Value Added and its components using a pyramidal metrics system INFA.

Since INFA was developed primarily for Czech companies, we add the largest Czech company Vodňanská drůbež, JSC and data on Czech food industry for comparison with the results of Kazakhstan companies. EVA analysis provides the information whether the company is generating economic profit, or is only covering costs. Altogether, these results draw a larger picture of financial situation of the companies competing at the market in question.

The objective of this research is to analyze competitiveness through financial performance of each company using publicly accessible accounting data as of 2013-2017 with all the mentioned models to see the trends of the sector as well as of individual companies. The hypothesis is that only financially healthy and EVA-creating companies can be successful, thus competitive, in the long run. Positive EVA is the precondition for being able to fund innovations, to reinvest and stay competitive in the long run.

We are aware that the analyzed companies are operating in two very different countries, however, their accounting environments are relatively similar as both use IFRS. Kazakhstan-based companies selected for our analysis have been obliged to follow IFRS since 2007 (KZ Law 234/III, 2007). Therefore, using Czech INFA system and utilizing Czech IFRS data allow for greater relative comparability than the US-based systems or the systems developed using data from other post-communist countries.

According to the Union of Poultry Farmers of Kazakhstan (Ptica.kz, 2018) about half of the poultry meat production is being imported. Kazakhstan is self-sufficient in egg production though. According to (Ptica.kz, 2018) the export of eggs was zero in 2010 increasing since. In 2016 it reached 156 million pieces, with the plan being to export $800 \mathrm{mln}$ in 2019. Imported eggs reached the level of $217 \mathrm{mln}$ pieces, on the other hand, import was $217 \mathrm{mln}$ in 2010 and $240 \mathrm{mln}$ in 2011 but falling since then to $40 \mathrm{mln}$ in 2016, and estimated to be $25 \mathrm{mln}$ only in 2019. The poultry sector production grew steadily from 70000 tons in 2008 to 153000 tons in 2016, planning to reach 346000 tons in 2019. The consumption does not grow 
that fast, so the share of domestic production increased from $37 \%$ in 2008 to $47 \%$ in 2016 with the plan to reach $81 \%$ in 2019 .

Kazakhstan poultry sector strengths are availability of food supply in the country (feed grain) and fast return on investment due to high genetic growth and feed conversion rates. The weaknesses are increasing costs; limited pricing as this is a socially significant product; relatively high share of imported raw materials; and a relatively low share of domestic poultry meat production; the presence of poor quality and "gray" imports of poultry products at the market; administrative and trade barriers.

The opportunities for the sector lie in the structure of meat consumption, as the share of poultry meat increases. As estimated by (Ptica.kz, 2018) it became most-produced meat in 2017 when it took over pork. Besides increasing domestic production, another opportunity is export, promotion of the culture of chilled poultry meat consumption and replacement of frozen imports. The threats are increasing supply of cheap imports; dumping, deterioration of the epizootic situation in the country and the world; high volatility in commodity prices.

Five selected companies, of which four are from Kazakhstan, primarily produce meat and their market share at the egg market is below 1\% (Ptica.kz, 2018). Similarly, Sever Ptica which can be considered as a medium-sized company at the egg market while it does not produce any significant market quantity of secondary products as meat.

Earnings after taxes of the analyzed companies in mln CZK (recalculated using official CZKKZT rate of NBK (NBK, 2018) so that to compare Kazakhstan companies to the largest Czech producer Vodnanska drubez) are as follows: Alatau-Kus (61), U-K pticefabrika (140), Sever Ptica (-10), Alel-Agro (361), Vodnanska drubez (186).

The companies' market shares at the primary commodity market in Kazakhstan are as follows: Alatau-Kus (10\%, meat, 15200 tons), U-K pticefabrika (17\%, meat, 25300 tons), Sever Ptica (3\%, eggs, 88 ths pcs.), Alel-Agro (24\%, meat, 34600 tons), Vodnanska drubez (137000 tons). (Ptica.kz, 2018; Euro, 2017). Source of the enterprise data are as follows: Alatau Kus: (AKUS, 2018), (Flagma, 2018), U-K pticafabrika: (Group Aitas, 2018), Sever ptica: (IAE, 2018), (Almaty. HH, 2018), Alel-Agro: (Alel-Agro, 2018), (EMIS, 2018), Vodnanska drubez: (SZIF, 2015)

\section{LITERATURE REVIEW}

Any organization, no matter how successfully it functions, is constantly faced with threats from the external environment. A common misconception is a view that anti-crisis analysis is a form of competent bankruptcy of an enterprise, while it can be an effective tool for managing a company in the course of its operation. Crisis management creates more favorable conditions for the company to create a competitive advantage, which allows it to produce products consumed by the market and receive enough money for the further development of the organization (Ganebnykh, 2017). Firms with lower profitability would have a higher possibility of financial distress (Kazemian, 2017).

In our study, we use financial indicators to measure variables that can be used as proxies of competitiveness measurement. Several studies confirm such an approach is possible. Sirikrai \& Tang (2006) note that „financial indicators such as return on investment and return on assets are the conventional proxies of competitiveness. Financial health can be assessed by profitability ratios and cash flows." Jacobi (1992) writes that "Financial analysis is an integral part of the competitive analysis process. Understanding the financial structure of your competitors and the industry provides insight into their possible courses of action and competitive responses." Wu, Zhang, Yeh, \& Chen (2013) conclude that "An important decision indicator of the airline competitiveness - a financial performance indicator that directly affects an airlines' survival. Financial performance indicators are mainly in the form of financial ratios, and the data can be retrieved from the airline's balance sheet, income statement, and cash flow 
statement." The liquidity and cash flow also have a direct impact on company competitiveness as Kroes \& Manikas (2014) write "Prevalent working capital management theory advocates that firms can improve liquidity, and hence their competitive positioning by manipulating their cash flow." Zanotti, Reyes, \& Fernandez (2018) in their article analyzing competitiveness in the brewing industry "illustrate the association between the competitiveness of the industry and financial performance."

Publicly accessible analyses of Kazakhstan companies' financial situation are not commonly available as they are in the Czech Republic. However, the popularity of this research field is recently on the increase. (Janshanlo, Noyanov, \& Andybayeva, 2016). (Sansyzbayeva \& Zhidebekkyzy, 2015) used catastrophe theory on chosen companies from various sectors concluding the "approach can predict on time a developing mismatch in a company's structure and define the moment of entering a critical zone." Another group of authors (Alimbekova, Baidildina, \& Dzhakisheva, 2017) created a formula for calculation of efficiency of financial recovery. Competitiveness of the companies is a dynamic indicator rather than a constant indicator. (Orazgaliyeva, 2018) Research using financial indicators has been done in Kazakhstan by Saylaubekov \& Dzhumadilova (2015) who assessed "financial and economic conditions [of two companies from the oil and gas sector] using six blocks of indicators, such as profitability, position on the securities market, liquidity and solvency, property status, business activity and financial independence." However, they note the research was not sector-specific.

Nevertheless, we are not aware of any research of companies in Kazakhstan using various bankruptcy models and putting them in context with INFA, Du Pont, ZVEI, RL or other indicator systems.

According to (Neumaier \& Neumaierová, 2002) the IN models belong to the group of bankruptcy models made for the conditions of the Czech restructuring market during the 1990s. The authors using discriminant analysis, ratios and weighted mean values created a function for identification of bankrupting companies. IN models has gone through several phases of evolution, the first being the IN95 index, which focuses on the company from the creditor's point of view and includes Past due liabilities, an indicator not being published by companies in Kazakhstan (so we cannot use it in our analysis). IN95 also takes into account what sector an enterprise belongs. Then the IN99 index followed, which assesses the company from the perspective of the owner. The model is thus able to identify whether an enterprise is creating new value for the owners. This model can, therefore, indicate the sustainability of the company's competitiveness. The IN99 index may be a suitable indicator of value creation, especially if it is not possible to work with market prices of the company's shares due to their low ability to report and/or the cost of equity. According to Sedláček (2001) this can often be the case of publicly traded companies that do not disclose other than narrowly set accounting information, give no investor guidance on markets with infrequent trades or low liquidity (Novotna, 2014).

IN01combines the merits of both the credit and the bankruptcy models and can be used by both owners and creditors. Its construction was based on a discriminatory analysis and was based on the data of 1915 enterprises that were divided into three groups: 583 enterprises were in the value-added enterprise group, 503 enterprises in bankruptcy or just before bankruptcy and 829 other enterprises $=$ a sample for defining the model extensively and therefore very representative. The model can identify, on the one hand, whether the firm creates economic value and at the same time to advise on the likelihood of bankruptcy.

The IN01 connects both of the previous indexes. The last version emerged in 2005 when IN01 was updated into the bankruptcy index IN05 (Neumaierová \& Neumaier, 2008).

The IN05 index is an update of the IN01 index according to the Industrial Data Tests of 2004. In addition to assessing whether or not the company shortly files for the bankruptcy of IN95, the indexes IN01 and IN05 also deal with whether the company also creates value for its owners. Advantages of IN05 are that its calculation is simple, financial algorithms are transparent, works with publicly available 
business finance data, it can be used for both the businesses publicly traded and not publicly traded on the capital market, gives clear results, and it is appropriate to be used as a complement to the parallel indicator system. However, users must take into account that the IN05 index was created and tested using the data of predominantly medium and large industrial enterprises, so for these companies, its information capability will be the best, works with annual business performance data. Therefore, it is a performance statement of an enterprise within an annual time horizon, is a rough indicative characteristic for the whole performance of the business, but it does not address how that performance has been achieved. (Neumaierová \& Neumaier, 2005)

The success rates of the models are according to their authors (Neumaierová \& Neumaier, 2005) as follows: the IN95 model has a success rate of 75\%. The IN99 success rate is $85 \%$. The IN01 success rate $74 \%$ and the IN05 success rate is $83 \%$ for creation value prediction and $77 \%$ for bankruptcy prediction. The bigger the company, the higher the success rate. When a business falls below the bottom of the index, it can be said that with $97 \%$ probability files for bankruptcy and in $76 \%$ of cases will not generate value. The enterprise in the grey zone will have a practically $50 \%$ probability of bankruptcy, and $70 \%$ will generate value. Undertakings above the upper limit will have a $92 \%$ probability of non-bankruptcy and a $95 \%$ probability of value creation.

We are aware that analyzed companies operate in different countries while do not face too different accounting environments as all use IFRS. Kazakhstan based companies used in our analysis are obliged to follow IFRS since 2007 (KZ Law 234/III, 2007). Therefore, using Czech INFA system utilizing Czech IFRS data allow greater relative comparability than US-based systems or systems developed using data from other than post-communist countries.

In 1991 (Stewart \& Stern, 1991) published a new metric "Economic Value Added (EVA)" that, based on their analyses, drives shareholder value in a better way than other performance measures. As (McClure) wrote: "EVA is a performance metric that calculates the creation of shareholder value, but it distinguishes itself from traditional financial performance metrics such as net profit and earnings per share (EPS). EVA is the calculation of what profits remain after the costs of a company's capital - both debt and equity - are deducted from operating profit. The idea is simple but rigorous: true profit should account for the cost of capital."

In 2007 the Czech Ministry of Industry and Trade in cooperation with the University of Economics in Prague developed and started INFA analysis for all Czech companies. The system is based on 18 indicators. The INFA Indicator System (INFA is a registered trademark of Inka and Ivan Neumaier) used economic added value as the core business performance indicator. INFA is the basic instrument of the reference analysis, which is implemented and published annually by the Ministry of Industry and Trade of the Czech Republic. The INFA Indicator system is a pyramidal breakdown of EVA. The first version of this system was made public 2007, and the most recent update took place in 2012. The system was developed using data of Czech industrial companies collected primarily by the Czech statistical office.

To proceed with such an analysis, we have chosen several models popular for measuring the likelihood of bankruptcy or solvency conditions IN models developed in the Czech Republic (including INFA system), which were developed using data from thousands of companies. This contrasts with tens of companies on which the other models are based. Each model uses different ratios and variables to provide a similar result as the likelihood of bankruptcy or corporate well-being. Therefore, we assume it is beneficial to use more models, compare and comment on their results. EVA analysis provides the companies information if the company is generating economic profit or is only profitable to cover opportunity costs or fares even worse than that. Altogether, these results create a big picture of the financial situation of companies competing in the selected market.

The objective of this research is to analyze competitiveness through the financial performance of each company using publicly accessible accounting data during 2013-2017 with all mentioned models to 
see the trends of the sector as well as of individual companies. The hypothesis is that only financially healthy and EVA (economic profit) creating a company can be successful, thus competitive, in the long run. Positive EVA is the condition for being able in the long run to fund innovation, to reinvest and stay competitive.

\section{METHODOLOGY}

As sources of our data, we used analytical websites and portals, such as Kase.kz and Dfo.kz, reports and websites of poultry companies, media files.

In order to analyze poultry business competitiveness using financial analysis indicators, we selected joint stock companies that do have reporting obligation: Alatau-Kus JSC, and Ust-Kamenogorskaya ptice fabrika JSC, and two non-publicly traded companies All-Agro JSC, and Sever Ptica JSC. Other companies' data, mostly limited liability companies are not available. One more company which is JSC is AkmolaFeniks, but besides financial data, the only available information (Shanyrak, 2018) is that it is primarily a grain producer without membership in the Union of Poultry Farmers of Kazakhstan (Ptica.kz, 2018). It is also part of Shanyrak group where one of the subsidiaries - its sister companies - is also Capital Projects Ltd. with a 6\% poultry meat market share (Ptica.kz, 2018) but as it is Ltd. company without any available financial data. Therefore, no company of the Shanyrak group was included in this analysis.

We analyzed competitiveness through the financial performance of each company in the chosen sector that disclosed publicly accessible accounting data during 2013-2017. Few selected companies have not published data beyond this period so we did the analysis using available comparable data.

To analyze financial trends and health in order to analyze financial performance and competitiveness of individual companies, we use (considering the availability of indicators) the following bankruptcy models that do not work with market value of a company, and thus are more suitable for analysis of companies operating on markets where its value can be quantified only with difficulty: IN99, IN01, IN05. Besides the mentioned models, we also analyzed how companies create economic profit (Economic Value Added) using Czech Benchmarking Diagnostic System of Financial Indicators INFA (MPO , 2018). Hájek et al. (2017) analyzed the confectionery sector in Kazakhstan during 2007-16, using bankruptcy and creditworthiness indicators including the IN models.

Unlike other pyramidal models, IN models were created and tested on data of industrial enterprises under the conditions of the Czech Republic, where IFRS is the accounting standard for many years as well as is for joint-stock companies in Kazakhstan since 2007. Hence are more suitable for companies from Central Asia than models developed using US data where besides different market conditions and regulation also accounting standards are different and likely play an important role.

Bankruptcy models indicate the probability of major financial difficulties for the company. The link between bankruptcy models and EVA is very simple: the company that creates economic value is moving away from the bankruptcy alarm zone(s) and vice versa.

Sometimes it may happen that the company even shows a positive EVA, and at the same time, a bankruptcy model puts it in the bankruptcy zone. The explanation usually lies in the fact that the company has a high return on equity, but at the same time, it can have a high indebtedness, low liquidity, and/or low operating performance, which the models evaluate as alarming.

In other words, it is necessary to consider the economic profit, which is the difference between revenues and economic costs. The economic concept of costs is the most comprehensive concept of costs. In addition to costs in financial terms, they also include opportunity costs, which represent the aggregate valuation of inserted resources. The goal of EVA is to show ways in which value appreciates or depreciates in time. Regarding the value of such an indicator (Maditinos, Šević, \& Theriou, 2006) who analyzed 161 companies listed on Athens Stock Market write: "Relative information content tests reveal 
that stock returns are more closely associated with earnings per share than with EVA (EVA is a registered trademark of Stern Stewart \& CO). However, incremental information content tests suggest that EVA adds considerable explanatory power to earnings per share in explaining stock returns." In other words, it is not a magic indicator that would say everything but indeed an important competitiveness indicator that can show much useful information.

EVA is determined by three variables: 1. Net Operating Profit After Tax $-N O P A T, 2$. Capital $-C$, and 3. Weighted Average Cost of Capital - WACC as:

$$
E V A=N O P A T-C \times W A C C
$$

Where NOPAT is the 'Net Operating Profit after Tax,' it is the economic result achieved in respect of the main business activity of the enterprise. Capital $C$ is the value of the company's financial resources, which was invested by all investors. WACC takes into account all the capital providers and reflect the fact that capital costs are not held only by borrowers through interest, but also by owners through opportunity costs.

Kislingerová Eva et al (2010), (2008) and (Mařík \& Mař́́ková, 2005) understand the Capital as capital tied to the assets needed to generate an operating profit. In connection with this, however, the question arises as to how these authors look at the part of assets covered by commitments that do not require a reward. (Mařík \& Mař́ková, 2005, str. 47) report: "We exclude the value of assets funded by non-interestbearing short-term liabilities from operating assets." Mařík and Maříková, therefore, consider not only the assets but also the sources of their coverage when determining the capital invested. Interestingly, consideration is also given to the fact that the authors exclude only short-term non-interest-bearing liabilities from assets generating an operating profit, although it would be assumed that any non-interestbearing liabilities would be excluded irrespective of their time character.

We can make certain transformations to this equation to simplify further calculations:

$$
\begin{gathered}
E V A=N O P A T-W A C C \times C \\
E V A=R O I C \times C-W A C C \times C \\
E V A=R O I C \times C-C\left(r_{d}(1-T) \frac{D}{C}+r_{e} \frac{E}{C}\right) \\
E V A=R O I C \times C-r_{d}(1-T) D-r_{e} E \\
E V A=\left(R O I C-r_{d}(1-T) \frac{D}{C}-r_{e} \frac{E}{C}\right) \times C \\
E V A=E A T-r_{e} E \\
E V A=R O E \times E-r_{e} E \\
E V A=\left(R O E-r_{e}\right) \times E
\end{gathered}
$$

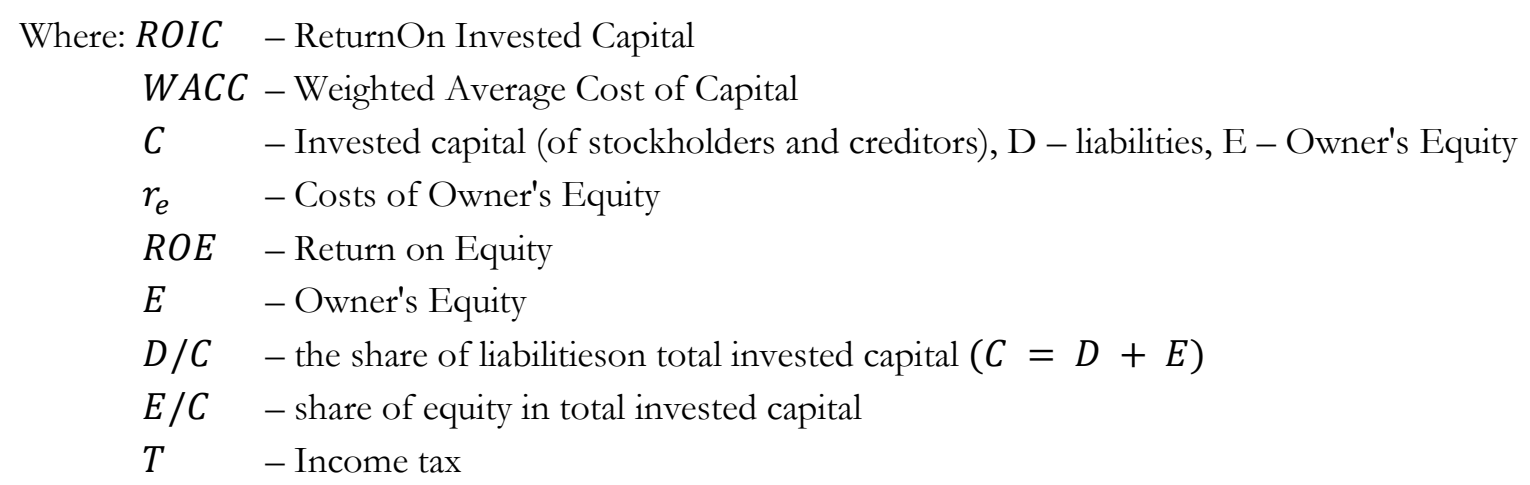


While

Asset-based calculation: $C=$ fixed assets + net working capital and thus

net working capital $=$ current assets - short_term liabilities

Liabilities-based calculation: $C=$ Liabilities - short_term liabilities

Further, we will work with equation (2) as all three variables are easy to obtain through the INFA Indicator system.

Key INFA Assumptions:

1. The actual or estimated interest rate shall be set at the cost of the liabilities.

2. The market value of liabilities is equal to the book value of interest-bearing liabilities.

3. Independence of the weighted average cost of capital (WACC) on the capital structure is assumed. Changing the capital structure merely reallocates the total cost of capital between the owners and creditors.

4. In the WACC formula, the (1 - income tax rate) characterizing the taxation used a share of net profit EAT on EBIT profit to reflect the actual impact of taxation.

5. An EBIT is estimated using Operating Profit value.

According to INFA methodology (Neumaier, INFA Methodology, 2012), risk estimate is a combination of algorithmizable relationships with probability characteristics. In principle, the INFA rating model approaches to risk assessment as a rating agency. Due to the existence of mathematical and statistical analyses, based on the available financial data of the company, it is possible to set up a function that would lead to comparable results with a rating agency. INFA works with different types of risks. In the online calculation interface, it is possible to add to the risk-free premium, which is determined as the yield of 10-year government bonds, own risk premium or let the INFA model itself calculate risk margin(and therefore $r_{e}$ ) automatically using its own database. We let the INFA model calculate $r_{e}$ automatically. INFA itself decomposes the risk premium on (i) the risk premium for the financial structure, (ii)the risk premium for the financial stability, (iii) the risk premium for the business risk (this is set by the Ministry of Industry and Trade for each sector and year), and on (iv) the risk premium for the size of the enterprise and the liquidity as:

$$
\begin{gathered}
r_{e}=f(\text { risk }- \text { free rate })+R P(\text { risk margin }) \\
R P=r F I N S T R U+r F I N S T A B+r P O D+r L A
\end{gathered}
$$

Where $r$ FINSTRU - risk premium for financiathe 1 structure;

rFINSTAB - risk premium for financial stability;

$\quad r P O D-$ risk premium for business riskspecified in the mpo table for eachsectors and years (oscillating around $3 \%$ );

$r L A \quad-$ risk premium for company size and liquidity.

The Costs of Owner's Equity $r_{e}$ futhenction is set to rely only on available data and was appropriate for chthe osen industry risk estimation. The level of risk represents alan ternative cost of owner's equity where $r_{e}$ is the return on capital that could be achieved in the case of an investment in an alternative (equally risky) investment opportunity. It is a complex way of opportunity costs calculation.

ROE calculation according to INFA (Neumaier, 2012):

$$
R O E=\frac{E A T}{E B I T} \times \frac{\frac{E B I T}{A}-\left(I R\left(\frac{M S}{A}-\frac{O E}{A}\right)\right)}{\frac{O E}{A}}
$$

Where: 
ROE - Return on Equity, EBIT - Earnings before Interest and Taxes, EAT - Earnings after Taxes, A - Assets, IR - Estimated interest rate, MS - money sources (equity + bonds + bank loans), OE Owner's Equity.

It is important to see the company as a complex mix of various stakeholder's interests. Besides the founder, who risks most and deserves the highest reward there are also shareholders, creditors, employees, suppliers, customers, who are interested in the profitable existence of the whole organization while each group has its interests. Customers ask for lowest prices and highest quality, suppliers ask for highest prices of delivered goods and services, shareholders highest return on their investment, employees for highest salaries possible and creditors for highest interest while owner for the highest return to offset his risk. For long-term profitability of the company, it all needs to be balanced.

Therefore, from a long-term perspective, one cannot focus only on financial indicators. The key is to find out causes that lead to the financial results and to focus on these causes. Balance scorecard is a method allowing that on the one hand. INFA does a similar job using different indicators.

Investors are thus looking for those businesses where: EVA $>0$, as the shareholder's wealth, grows in these businesses and the amount of EVA then determines how much money will remain for the company itself to invest in its further development (e.g., investments into innovations which is a prerequisite of long-term prosperity and competitiveness). Companies where EVA $=0$ produced the same amount they invested in terms of opportunity costs, which is not a desirable outcome as then the profit covers only dividends and the company lack funds for investments. In companies where EVA $<0$, a destruction of value for shareholders takes place as the company is not able to satisfy the requirements of creditors and/or owners.

Based on the equation (2) we can see that to have positive EVA we need $R O E$ greater than $r_{e}$ (opportunity costs) as then company creates economic value added.

To use the online INFA model we convert to CZK all accounting values in KZT, which are needed for all EVA calculations and use the end of the year exchange rate for each year included in the analysis during the 2013-2017 period. For CZK KZT exchange rate we use rates from the National Bank of Kazakhstan (NBK, 2018).

At each level of our analysis, we showed the results of using the IN and INFA models separately.

The IN index may be an appropriate indicator of value creation, especially if it is not possible to work with market prices for a company's shares due to their low ability to provide information or if no equity cost can be determined. With the success rate of $86.4 \%$, the index proves the value creation and with an even higher rate of success $98.9 \%$ has been able to identify that there is no value creation. (Atlantis, 2017)

$$
\text { IN99 }=-0.017 * A+4.573 * C+0.481 * D+0.015 * E
$$

Where:

$A=$ assets $/$ liabilities

$C=$ EBIT $/$ total assets

$D=$ sales / total assets

$E=$ current assets / short-term

liabilities
IN99 $>2.07$ The company creates a new value for the owner (dark green)

$1.42 \leq$ IN99 $<2.07$ Rather it creates value for the owner(green)

$1.089 \leq$ IN99 $<1.42$ It is not possible to determine whether or not a company creates

value for the owner(light blue)

$0.684 \leq$ IN $99<1.089$ Rather does not create value for the owner(red)

IN99 $<0.684$ Enterprise does not create value for the owner (dark red) 
Table 1

Results of IN99

\begin{tabular}{|l|c|c|c|c|c|}
\hline \multicolumn{1}{|c|}{ IN99 } & $\mathbf{2 0 1 3}$ & $\mathbf{2 0 1 4}$ & $\mathbf{2 0 1 5}$ & $\mathbf{2 0 1 6}$ & $\mathbf{2 0 1 7}$ \\
\hline Alatau-Kus & 0.80 & 1.41 & 0.91 & 1.16 & 1.21 \\
\hline U-K pticefabrika & 1.01 & 1.81 & 3.51 & 1.45 & 0.48 \\
\hline Alel-Agro & -1.16 & -2.81 & -3.13 & -0.77 & 1.68 \\
\hline Sever Ptica & -0.90 & -0.30 & -0.05 & 0.00 & -0.19 \\
\hline Vodnanska drubez & 1.37 & 2.04 & 2.03 & 1.98 & 1.96 \\
\hline
\end{tabular}

Source: Authors' calculations.

The IN99 index is as mentioned a creditworthiness model providing information on whether an enterprise is creating new value for the owners and thus indicates the sustainability of the company's competitiveness.

The results in Table 1 show that U-K ptica fabrika is the only one that created new value for the owner in 2015. What is a surprising result is Alel-Agro which values are even worse than those of Sever Ptica. The result is caused by big values of A and E ratios of the IN99 index. Thus, the company relies rather on relatively expensive owner's equity than on usually cheaper liabilities. However, that provides stability of the company minimizing risks like changing interest rates. Besides Sever Ptica which is losing value generally, also Alatau-Kus rather does not create value for the owner.

\section{IN01 Index}

The IN01 merges creditworthiness and bankruptcy models.

$$
\text { IN01 }=0.13 * A+0.04 * B+3.92 * C+0.21 * D+0.09 * E
$$

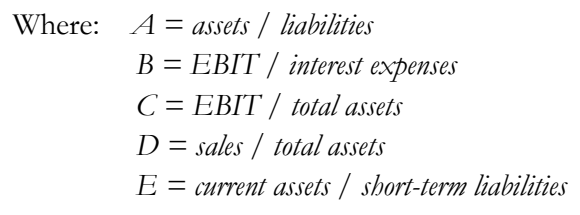

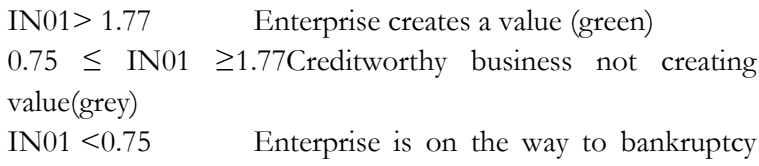

Table 2

Results of IN01

\begin{tabular}{|l|c|c|c|c|c|}
\hline \multicolumn{1}{|c|}{ IN01 } & $\mathbf{2 0 1 3}$ & $\mathbf{2 0 1 4}$ & $\mathbf{2 0 1 5}$ & $\mathbf{2 0 1 6}$ & $\mathbf{2 0 1 7}$ \\
\hline Alatau-Kus & 0.99 & 1.68 & 1.28 & 1.30 & 1.45 \\
\hline U-K pticefabrika & 1.94 & 3.15 & 4.16 & 9.07 & 5.14 \\
\hline Alel-Agro & 19.38 & 42.72 & 40.65 & 20.15 & 2.62 \\
\hline Sever Ptica & 0.42 & 0.02 & 0.66 & 0.66 & 0.54 \\
\hline Vodnanska drubez & 0.87 & 1.84 & 1.84 & 1.88 & 1.96 \\
\hline
\end{tabular}

Source: Authors' calculations.

Together with IN05, the IN01 uses interest expenses. To be able to run the analysis with comparable results we limit the ceiling of the ratio EBIT / Interest expenses to 9 if the result was to be higher (in absolute value as well) to limit distortion of the z-score result. In fact (Neumaier \& Neumaierová, 2002) note that in cases when the ratio would skyrocket up to infinity - including cases of zero interest expenses or serious problems with credit repayments, the nine is maximum value to be used. This ceiling we implement affects results of IN01 and IN05 for all the companies in almost all years.

The IN01 combines information about bankruptcy probability and value creation for the owner, and we see Alatau-Kus is not creating value for the owner during the whole period and as expected Sever Ptica is doing even worse with a high likelihood of bankruptcy. 


\section{IN05 Index}

IN05 is the latest known index of Inka and Ivan Neumaier. This index is an update of the IN01 index of the Industrial Data Tests of 2004. The ratios are same with IN01. The index formula IN05 is:

$$
\text { IN05 }=0.13 * A+0.04 * B+3.97 * C+0.21 * D+0.09 * E
$$

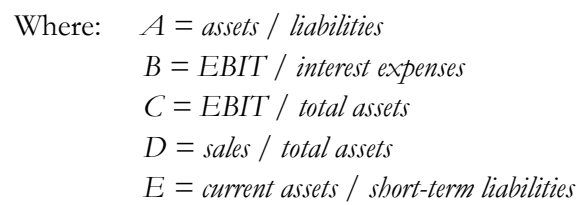

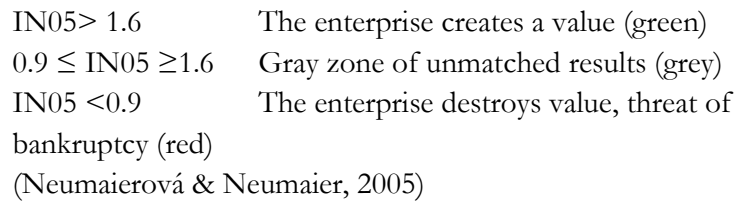

Table 3

Results of IN05

\begin{tabular}{|l|c|c|c|c|c|}
\hline IN05 & $\mathbf{2 0 1 3}$ & $\mathbf{2 0 1 4}$ & $\mathbf{2 0 1 5}$ & $\mathbf{2 0 1 6}$ & $\mathbf{2 0 1 7}$ \\
\hline Alatau-Kus & 0.99 & 1.69 & 1.28 & 1.31 & 1.46 \\
\hline U-K pticefabrika & 1.95 & 3.17 & 4.19 & 9.09 & 5.15 \\
\hline Alel-Agro & 19.39 & 42.74 & 40.66 & 20.17 & 2.64 \\
\hline Sever Ptica & 0.41 & 0.02 & 0.65 & 0.66 & 0.54 \\
\hline Vodnanska drubez & 0.87 & 1.84 & 1.84 & 1.89 & 1.97 \\
\hline
\end{tabular}

Source: Authors' calculations.

The IN05 results are similar to those of IN01; just interpretation is slightly different. Alatau-Kus creates value in 2014 while in other years positions in the grey area of unmatched results. Sever Ptica destroyed value in 2013, and during the whole period respectively

\subsection{INFA Indicator system and Economic Value Added}

To obtain INFA results the online system (MPO, 2007) requires 18 indicators; however, not all are mandatory for INFA calculation (the system also calculates other indicators besides EVA). Our analysis uses the following ones: Sales, Interest expenses, Earnings before income tax, earnings after taxes, Total Assets, Inventories, Account receivables, Short-term financial investments (does not include cash, only short-term securities), Owner's Equity (used in Altman as Market value of Equity), Short-term liabilities, Long-term bank and other borrowings, Short-term bank and other borrowings, and Production consumption ( $=$ material costs + energy costs + services). To use the online INFA model we convert to CZK all accounting values of Kazakh companies (in KZT) which are needed for all EVA calculations and use the end of the year exchange rate for each year included in the analysis during the 2013-2017 period. For CZK KZT exchange rate we use rates from the National Bank of Kazakhstan (NBK, 2018).

Table 4

Economic Value Added calculated using INFA Indicator system [CZK thousands]

\begin{tabular}{|l|c|c|c|c|c|}
\hline & $\mathbf{2 0 1 3}$ & $\mathbf{2 0 1 4}$ & $\mathbf{2 0 1 5}$ & $\mathbf{2 0 1 6}$ & $\mathbf{2 0 1 7}$ \\
\hline Alatau-Kus & $-5,922$ & 89,073 & 5,211 & 8,625 & 14,888 \\
\hline U-K pticefabrika & 116,268 & 472,472 & 375,175 & 251,418 & 75,458 \\
\hline Alel-Agro & 60,517 & 311,297 & 155,932 & 263,507 & 302,046 \\
\hline Sever Ptica & $-71,985$ & $-38,238$ & $-12,481$ & $-11,641$ & $-10,446$ \\
\hline Vodnanska drubez & $-100,738$ & 693 & 6,692 & 8,701 & 22,387 \\
\hline
\end{tabular}

Source: Authors' calculations using online INFA analysis results. 
In Table 4 we see Sever Ptica is slowly catching up to start generating Economic Value Added and maybe soon will reach positive values. On the positive side, the U-K pticefabrika is faring much better than Alel Agro likely due to more effective optimization of capital costs.

Decomposition of the ROE is presented further where ATR is Asset Turnover Ratio (Sales/Assets), ROS is Return on Sales (EAT/Sales), FL is Financial Leverage (Assets/Owner's Equity), ROE is Return on Equity and ER is Equity Ratio which is a proportion of equity used to finance a company's assets (Owner's Equity/Assets). All indicators were calculated using online INFA calculation (MPO , 2018) ROE decomposition clearly shows the weaknesses and strengths determining ROEs - issues where they are lagging behind the competition and need to improve whether it be the profitability of sales, asset turnover or leverage.

Alatau-Kus

The ROE decomposition in Table 5 shows the ROE reaches high values during all years and especially in 2014 when it passes over an incredible $90 \%$. Asset turnover stays relatively unchanged with a one-year dive in 2015 of $14 \%$ but returning back in the next year changing only by few percents every year. ROS also gets to double digits over 10\%, which is good news and even better is it is relatively stable since 2015. Financial leverage is falling dramatically (with a relative pause in 2017) so the coefficient of self-financing ER increases. Therefore, the optimal use of foreign capital used to increase rentability is falling.

Table 5

Alatau-Kus ROE decomposition

\begin{tabular}{|l|c|c|c|c|c|}
\hline & $\mathbf{2 0 1 3}$ & $\mathbf{2 0 1 4}$ & $\mathbf{2 0 1 5}$ & $\mathbf{2 0 1 6}$ & $\mathbf{2 0 1 7}$ \\
\hline ROS & $3.81 \%$ & $17.51 \%$ & $10.49 \%$ & $10.93 \%$ & $11.46 \%$ \\
\hline ATR & 1.00 & 0.97 & 0.83 & 1.00 & 1.03 \\
\hline FL & 6.07 & 5.35 & 3.59 & 2.96 & 3.11 \\
\hline ROE & $23.22 \%$ & $90.44 \%$ & $31.40 \%$ & $32.24 \%$ & $36.89 \%$ \\
\hline ER & $16.47 \%$ & $18.70 \%$ & $27.86 \%$ & $33.77 \%$ & $32.15 \%$ \\
\hline
\end{tabular}

Source: Authors using online INFA analysis results.

Ust-Kamenogorskaya ptice fabrika

The ROE decomposition of Ust-Kamenogorskaya ptice fabrika in Table 6 shows high ROE with high ROS, increasing asset turnover and very high equity ratio (i.e., very low financial leverage). The company is thus using primarily own capital avoiding dependence on foreign capital.

Table 6

Ust-Kamenogorskaya pticefabrika ROE decomposition

\begin{tabular}{|l|c|c|c|c|c|}
\hline & $\mathbf{2 0 1 3}$ & $\mathbf{2 0 1 4}$ & $\mathbf{2 0 1 5}$ & $\mathbf{2 0 1 6}$ & $\mathbf{2 0 1 7}$ \\
\hline ROS & $19.49 \%$ & $48.00 \%$ & $62.17 \%$ & $32.36 \%$ & $16.59 \%$ \\
\hline ATR & 0.64 & 0.68 & 0.94 & 1.02 & 0.71 \\
\hline FL & 1.40 & 1.24 & 1.30 & 1.09 & 1.13 \\
\hline ROE & $17.63 \%$ & $40.59 \%$ & $76.02 \%$ & $36.00 \%$ & $13.26 \%$ \\
\hline ER & $71.21 \%$ & $80.71 \%$ & $76.85 \%$ & $91.47 \%$ & $88.88 \%$ \\
\hline
\end{tabular}

Source: Authors using online INFA analysis results.

Sever Ptica

The company from the north of Kazakhstan likely faces the high competition of imported cheaper eggs from Russia, is increasing still negative Return on Sales, its asset turnover slowly increases as is financial leverage. 
Tengrinews (TN, 2014) announced that an investigation about abusing dominant market position by Sever Ptica had been closed with the confirmatory court decision. The company increased the prices in the fall of 2013 due to weak summer sales and increasing prices of eggs on the Russian market. The company never plead guilty to collusion (a secret agreement between two or more parties to limit open competition by deceiving) blaming incompetent government officers of Agency of the Republic of Kazakhstan for the Protection of Competition. Another company AZK chicken has also been set guilty by the court. Less than a year later has been asked by the regional prosecutor's office to pay 3087 thousand tenges (16800 USD) due for unpaid wages in January 2015 (KN, 2015).

Had the company experienced a better 2017 in terms of earnings, we could say it is on a good trajectory to significantly decrease its probability of bankruptcy. The situation is still dire and needs to improve soon; otherwise the company will fail.

Table 7

Sever Ptica ROE decomposition

\begin{tabular}{|l|c|c|c|c|c|}
\hline & $\mathbf{2 0 1 3}$ & $\mathbf{2 0 1 4}$ & $\mathbf{2 0 1 5}$ & $\mathbf{2 0 1 6}$ & $\mathbf{2 0 1 7}$ \\
\hline ROS & $-57.46 \%$ & $-33.29 \%$ & $-10.90 \%$ & $-9.34 \%$ & $-15.22 \%$ \\
\hline ATR & 0.38 & 0.37 & 0.51 & 0.77 & 0.76 \\
\hline FL & 2.79 & 3.64 & 4.22 & 7.68 & 37.33 \\
\hline ROE & $-61.56 \%$ & $-44.35 \%$ & $-23.40 \%$ & $-55.00 \%$ & $-433.98 \%$ \\
\hline ER & $35.88 \%$ & $27.44 \%$ & $23.71 \%$ & $13.02 \%$ & $2.68 \%$ \\
\hline
\end{tabular}

Source: Authors using online INFA analysis results.

Alel-Agro

Together with Ust-Kamenogorskaya ptice fabrika this company generates positive EVA in all analyzed years. It shows high ROE and ROS above $20 \%$, and since 2016 increasing financial leverage. Asset turnover, i.e., the effectivity how the company uses assets, is slightly falling. The values of high equity ratio above $60 \%$ point to the extensive usage of their own capital to finance assets. Although we believe Alel-Agro could easily borrow at relatively low-interest rates, it neither wants nor needs to borrow.

Table 8

Alel-Agro ROE decomposition

\begin{tabular}{|l|c|c|c|c|c|}
\hline & $\mathbf{2 0 1 3}$ & $\mathbf{2 0 1 4}$ & $\mathbf{2 0 1 5}$ & $\mathbf{2 0 1 6}$ & $\mathbf{2 0 1 7}$ \\
\hline ROS & $14.72 \%$ & $29.06 \%$ & $25.18 \%$ & $25.64 \%$ & $24.78 \%$ \\
\hline ATR & 0.97 & 1.10 & 0.99 & 0.88 & 0.99 \\
\hline FL & 1.48 & 1.18 & 1.08 & 1.40 & 1.46 \\
\hline ROE & $21.11 \%$ & $37.69 \%$ & $26.98 \%$ & $31.39 \%$ & $35.65 \%$ \\
\hline ER & $67.42 \%$ & $84.70 \%$ & $92.52 \%$ & $71.49 \%$ & $68.63 \%$ \\
\hline
\end{tabular}

Source: Authors using online INFA analysis results.

Vodnanska drubez

The Czech company is in a similar situation to using more own capital to finance assets in recent years as Alel Agro, Ust-Kamenogorskaya pticefabrika, and Alatau-Kus. Its ROE increased significantly between 2013 and 2014. The asset turnover remains relatively unchanged and ROS although positive stays at low values. Anyway, the company is generating higher EVA every analyzed year compared to the previous year, and that is good news for the owner. 
Vodnanska drubez ROE decomposition

\begin{tabular}{|l|c|c|c|c|c|}
\hline & $\mathbf{2 0 1 3}$ & $\mathbf{2 0 1 4}$ & $\mathbf{2 0 1 5}$ & $\mathbf{2 0 1 6}$ & $\mathbf{2 0 1 7}$ \\
\hline ROS & $-0.21 \%$ & $3.07 \%$ & $3.06 \%$ & $3.29 \%$ & $3.48 \%$ \\
\hline ATR & 2.89 & 3.05 & 3.13 & 2.99 & 3.01 \\
\hline FL & 3.09 & 2.32 & 1.94 & 1.73 & 1.50 \\
\hline ROE & $-1.84 \%$ & $21.68 \%$ & $18.53 \%$ & $17.04 \%$ & $15.72 \%$ \\
\hline ER & $32.36 \%$ & $43.14 \%$ & $51.57 \%$ & $57.67 \%$ & $66.58 \%$ \\
\hline
\end{tabular}

Source: Authors using online INFA analysis results.

The analysis showed the Sever Ptica is trying hard to postpone bankruptcy, and maybe it will succeed this or next year, maybe it will fail. Alel-Agro is a successful company independent of foreign capital financing with likely very popular products in Kazakhstan which is a large country with almost double the population compared to the Czech Republic. Transport in Kazakhstan is still relatively affordable, and therefore, companies can compete with each other relatively well. The models and other sources show that the market has still much space to grow. Given the economic situation and its outlook in Kazakhstan, the poultry meat industry has many successful years ahead.

It is located in Almaty, while Ust-Kamenogorskaya pticefabrika, also a successful company, profits primarily from the north Kazakhstan market.

Czech food industry

For a complete picture, we also present results of EVA decomposition for the Czech food industry. It comprises many diverse corporations of different sizes.

Table 10

Food Industry CZ ROE decomposition

\begin{tabular}{|l|c|c|c|c|c|c|}
\hline & $\mathbf{2 0 1 3}$ & $\mathbf{2 0 1 4}$ & $\mathbf{2 0 1 5}$ & $\mathbf{2 0 1 6}$ & $\mathbf{2 0 1 7}$ & Average \\
\hline ROS & $3.1 \%$ & $3.9 \%$ & $3.4 \%$ & $4.2 \%$ & $4.6 \%$ & $3.9 \%$ \\
\hline ATR & 1.68 & 1.54 & 1.57 & 1.42 & 1.34 & 1.51 \\
\hline FL & 1.91 & 1.80 & 1.86 & 1.77 & 1.83 & 1.83 \\
\hline ROE & $9.9 \%$ & $10.9 \%$ & $10.1 \%$ & $10.6 \%$ & $11.3 \%$ & $10.5 \%$ \\
\hline ER & $52.2 \%$ & $55.7 \%$ & $53.7 \%$ & $56.4 \%$ & $54.7 \%$ & $54.5 \%$ \\
\hline
\end{tabular}

Source: INFA online analysis results.

Table 11

The best company in the Food Industry CZ ROE decomposition

\begin{tabular}{|l|c|c|c|c|c|c|}
\hline & $\mathbf{2 0 1 3}$ & $\mathbf{2 0 1 4}$ & $\mathbf{2 0 1 5}$ & $\mathbf{2 0 1 6}$ & $\mathbf{2 0 1 7}$ & Average \\
\hline ROS & $7.6 \%$ & $7.7 \%$ & $6.8 \%$ & $6.6 \%$ & $7.2 \%$ & $7.2 \%$ \\
\hline ATR & 1.60 & 1.49 & 1.86 & 1.61 & 1.7 & 1.65 \\
\hline FL & 1.70 & 1.64 & 1.79 & 1.54 & 1.54 & 1.64 \\
\hline ROE & $20.6 \%$ & $18.8 \%$ & $22.7 \%$ & $16.4 \%$ & $18.8 \%$ & $19.5 \%$ \\
\hline ER & $59.0 \%$ & $60.9 \%$ & $56.0 \%$ & $65.0 \%$ & $64.9 \%$ & $61.1 \%$ \\
\hline
\end{tabular}

Source: INFA online analysis results.

Even the best company in the Czech Republic in the food sector (can be different company each year) does not have such a high ROE as Alel-Agro, Alatau-Kus or Ust-Kamenogorskaya pticafabrika. Czech highly competitive market being part of the European Union offers cheap financial market financing with low-interest rates in an environment of low inflation compared to Kazakhstan. Companies 
from Kazakhstan have financial leverage values close to the average of the Czech market and have much lower values of Asset turnover. The best Czech food industry company has higher values of financial leverage than Ust-Kamenogorskaya ptice fabrika or Alel-Agro. This points to the still-developing market with growth potential.

Our hypothesis has been confirmed. We have shown all companies although they faced many issues since 2013, evaded bankruptcy, and we also show periods when they generated EVA about when they struggled to survive using analytical metrics.

\section{EMPIRICAL RESULTS AND DISCUSSION}

Business environments vary across the Globe. In the Czech Republic or Kazakhstan, we can say there is a different perception of the risk associated with the indebtedness rate. If it is common in the US that companies have up to $80 \%$ foreign capital, then in environments analyzed by us that would be hard to accept by both the management of companies and the creditors in particular. We consider it healthy to stick to the golden rule of financing when own and foreign capital are almost balanced. Therefore, we consider IN models to be much more suitable for analyzing companies operating in post-socialist countries of Eastern Europe or Central Asia than other models.

The IN models can be very well used in Kazakhstan because they do not work with the market value of the company indicators, given that in the economic conditions of the Czech Republic and other postsocialist countries its value can be quantified only with difficulty. This is primarily due to the low explanatory power of capital market pricing data, especially for companies whose securities are traded with very low liquidity levels. This is of course also the case of Kazakhstan, for which the Czech models are more suitable than other models that were designed for the analysis of companies operating in much more liquid and advanced market environments.

Proper management certainly needs experience with local market specifics. The market in Kazakhstan is due to political and economic influences in a permanent change and management of the companies need to be able to adapt quickly. Another specific of the whole market is high-interest rates causing fluctuating and hardly predictable interest expenses of all indebted companies. This forces the companies to prefer their own capital to a foreign one in the expansion. That explains why Kazakhstan companies try to use a much lower amount of debt.

Such a business environment cannot be called standard by European terms, and for more effective financial analysis the managers would probably appreciate a similar approach as in the Czech Republic. There the Ministry of Industry and Trade through cooperation with the University of Economics in Prague operates a web portal where every company can enter their data and receive model results and most important comparison with the rest of the sector. In financial analysis, it is always very difficult to calculate the Costs of Owner's Equity while the INFA system solves this problem. The system can take into account and quantify the whole range of risks that are reflected in the risk premium for the financial structure, financial stability, business risk, size of the company and liquidity. It is also possible to work with the impact of return on sales, turnover, and leverage due to the possible decomposition of the factors influencing the profitability of equity.

The INFA model shows it provides several very useful competitiveness variables and based on our research it shows interesting results and can be beneficial. Our analysis shows that the IN models with INFA Indicator System can be effectively used for competitiveness analysis or financial performance of companies from other post-communist countries including Kazakhstan.. 


\section{CONCLUSION}

The analysis presented various IN models in order to confirm hypothesis only the financially healthy company can create economic value and thus stay competitive. This hypothesis has been confirmed.

Evaluation of presented results is not straightforward as each model is slightly different even if they fall in same (bankruptcy, creditworthiness, or mixed) family of models. The results need to be read in this context, so it is impossible to say which model is the best or worst one. Some presented models assign a higher priority to liquidity than to rentability, some point to the higher probability of economic profit creation. A company can have big profits or generate EVA, yet it can be just before bankruptcy because the company does not care about adequate indebtedness and liquidity while it focuses only on top performance (while this is not the case of analyzed companies). Such a company situation would be similar to a runner who is overpowered by various aids (in company's case it can be debt) and collapses behind the target tape with a world record, but unable to race again.

Further studies are needed to estimate the effects of IN and INFA models for other sectors of the economy.

\section{REFERENCES}

AKUS. (2018, November 23). Alatau-Kus. Retrieved from Alatau-Kus site: http://akus.kz/ru Alel-Agro. (2018, November 23). alelagro.k\% Retrieved from About the company Alel-Agro: http://alelagro.kz/ru/company.html

Alimbekova, G., Baidildina, A., \& Dzhakisheva, U. (2017). Ways of Financial Recovery and Prevent Bankruptcy. Journal of Engineering and Applied Sciences, 12(3), 653-659.

Almaty HH. (2018, November 23). Sever ptica AO. Retrieved from Almaty Head Hunter: https://almaty.hh.kz/employer/1196177

Atlantis. (2017). Used bankruptcy and creditwortby models. Retrieved from http://www.finanalysis.cz/pouzite-bankrotnimodely.html

EMIS. (2018, November 23). Company Overview Alel Agro AO. Retrieved from Emis store: https:///yck8vu6g

Euro. (2017, March 7). Vice kứat od Babišse. Vodñanská drübež navy̌š́ produkci o trétinu [More cbickens from Babis. Vodnanska drubez to increase production by one third]: Retrieved from euro.cz: https://www.euro.cz/byznys/vicekurat-od-babise-vodnanska-drubez-n

Flagma. (2018, November 23). flagma.kz. Retrieved from https://almaty.flagma.kz/879284/

Ganebnykh, E. (2017). Anti-crisis management as a way to improve the efficiency of enterprise management. Economy vector, 10(16), 34.

Group Aitas. (2018, November 23). About the company: https://aitas.kz/groups/2/

Hájek, P., Zhunissova, G., Čábelová, T., \& Baidildina, A. (2017). Competitiveness analysis of Kazakhstan confectionary sector using financial discriminant models, CBU International Conference Proceedings. In C. I. Proceedings, 144-153.

IAE. (2018, November 23). AO Sever Ptica. Retrieved from International Association of Organic Products Manufacturers: http://ecobiokz.wixsite.com/ecobio/ao-sever-ptica

Jacobi, G. (1992). Financial Tools for Competitive Analysis. Competitive Intelligence Review, 14-18.

Janshanlo, R. E., Noyanov, M. E., \& Andybayeva, G. (2016, December). Simulation of Company's Bankruptcy Probability based on Catastrophe Theory. Indian Journal of of Science and Tecbnology, 9(47), 1-12. 
Kazemian, S. S. (2017). Monitoring mechanisms and financial distress of public listed companies in Malaysia. Journal of International Studies, pp. 92-109.

Kislingerová, E. et al. (2010). Managerial Finance [Manažerské finance] (3 ed.). Praha: C.H. Beck.

Kislingerová, E. H. (2008). Financial analysis step by step [Finančni analýza: krok za krokem]. Praha: C.H. Beck.

KN. (2015, January 16). Directors of Kostanay poultry farm prosecuted for wage arrears. Retrieved from Kostanayskiye novosti [Kostanay News]:: http://kstnews.kz/news/society?node=19703

Kroes, J. R., \& Manikas, A. S. (2014). Cash flow management and manufacturing firm financial performance: A longitudinal perspective. Int. J. Production Economics, 37-50.

KZ Law 234/III. (2007, February 28). Retrieved from Law of the Republic of Kazakhstan "On Accounting and Financial Reporting" No. 234-III as ammended. Retrieved from: https://online.zakon.kz/Document/?doc_id=30092011

Maditinos, D. I., Šević, Ž., \& Theriou, N. G. (2006). Economic Value Added (EVA®). Is it really the best performance measure? A Review of the Theoretical and Empirical Literature. The case of Athens Stock. Exchange (ASE).

Martina Novotna, J.S. (2014). The economic results of farms in the Czech Republic. Journal of Central European Agriculture 15(4), 31-50.

Mařík, M., \& Maříková, P. (2005). Moderni metody hodnoceni výkonnosti a oceňování podniku. [Modern methods of enterprise performance evaluation and valuation.]. Praha: Ekopress.

McClure, B. (n.d.). (nd). All About EVA. Retrieved from Investopedia: https://www.investopedia.com/articles/fundamental/03/031203.asp

MPO . (2018, November 23). Benchmarkingový diagnostický systém finaníních indikátorů INFA [klasifikace CZ-NACE] [Benchmarking Diagnostic System of Financial Indicators INFA [CZ-NACE classification],. Retrieved from Ministry of Industry and Trade: https://www.mpo.cz/benchmarking/infa-v2.html

MPO. (2007). Bechmarking diagnostic system of INFA Financial Indicators. Retrieved from Ministry of Industry and Trade: https://www.mpo.cz/cz/rozcestnik/analyticke-materialy-a-statistiky/benchmarkingovy-diagnosticky-systemfinancnich-indikatoru-infa--30195/

NBK. (2018, November 23). Official (market) Exchange Rates. Retrieved from National Bank of Kazakhstan: https://nationalbank.kz/?furl=cursFull\&switch=eng

Neumaier, I. (2012, April 25). Retrieved from Ministry of Industry and Trade: https://www.mpo.cz/assets/cz/rozcestnik/analyticke-materialy-a-statistiky/2016/11/metodika-vypoctu.pdf

Neumaier, I., \& Neumaierová, I. (2002). Performance and market value of the company. [Výkonnost a trěni hodnota firmy]. Praha: Grada Publishing.

Neumaierová, I., \& Neumaier, I. (2005). Index IN05. Proceedings of the International Scientific Conference "European Financial Systems" [Sborník př̌spèvkì z. mezinárodni védecké konference "Evropské finanóni systémy"], 143-148. Brno: Masaryk University.

Neumaierová, I., \& Neumaier, I. (2008). Proč se ujal index IN a nikoli pyramidový systém ukazatelů INFA. Ekonomika management, $\quad$ (4). $\quad$ Retrieved from https://www.vse.cz/polek/download.php?lang=cz\&jnl=eam\&pdf=51.pdf

Orazgaliyeva, E. (2018). The theoretical aspects of competitive advantages as an object of marketing management. The Journal of Economic Research \& Business Administration, 4(126), 2-34.

Ptica.kz. (2018, November 23). Poultry Development Roadmap. Retrieved from Union of Poultry Farmers of Kazakhstan: http://ptica.kz/sites/default/files/dorozhnaya_karta_2017_g._sayt.ppt 
Sansyzbayeva, K., \& Zhidebekkyzy, A. (2015). Science, technology and humanities for business and economic sustainability. International conference on business and economics. Agricultural Innovations for Sustainable Development: Analysis of Situation in Kazakhstan and Ways for Improvement, 251-255.

Saylaubekov, N., \& Dzhumadilova, S. (2015). Rating assessment of the company's competitiveness based on the regulatory model. Bulletin of KazNU, economic series.

Sedláček, J. (2001). Finančni analýza v ř́zeni firmy [Financial analysis in company management] (2. vyd.). Brno: Computer press.

Shanyrak. (2018, November 23). Akmola-feniks JSC. Retrieved from Shanyrak group: http://shanyrakgroup.kz/page/child_company_01

Sirikrai, S. B., \& Tang, J. C. (2006, June 19). Industrial competitiveness analysis: Using the analyitic hierarchy process. Journal of High Technology Management Research, 71-83.

Stewart, G., \& Stern, J. (1991). The quest for value: The EVA management guide. New York: HarperBusiness.

SZIF. (2015, July). Zprava o trbu druberiho masa [Report on the market for poultrymeat] Retrieved from: Státní zemědělský intervenční fond Agrate Antervention https://www.szif.cz/cs/CmDocument?rid=\%2Fapa_anon\%2Fcs\%2Fzpravy\%2Ftis\%2Fzpravy_O_t

TN. (2014, March 17). The reason for the increase in prices for chicken eggs in Kazakbstan was the price collusion. Retrieved from tengrinews.kz:: https://tengrinews.kz/markets/prichinoy-povyisheniya-tsen-kurinyie-yaytsa-kazahstane-stal252098/

Wu, C., Zhang, X., Yeh, I., \& Chen, F. (2013, December 30). Evaluating competitiveness using fuzzy analytic hierarchy process - A case study of Chinese airlines. Journal of advanced transportation, 619-634.

Zanotti, C., Reyes, F., \& Fernandez, B. (2018, January). Relationship between competitiveness and operational and financial performance of firms: An exploratory study on the European brewing industry. Intangible Capital, 99115. 